\title{
A Study to the Cultural Diplomacy and Feminist Translation Theory
}

\author{
Liu Kexin \\ Department of Business English, Sichuan International Studies University, \\ Zhuangzhi Road, Shapingba District, Chongqing, China \\ 1079508491@qq.com
}

\begin{abstract}
In the process of globalization, relations among countries are getting closer and closer on account of countries depending on mutually economical and political influence. Basic translation is the sole channel for the communication of cross-cultural works. National governments hope to enhance their own influence and build a good image through the export of excellent cultural works to conduct cultural diplomacy. Among many translation theories, feminist translation has emerged as a way to highlight the status of women. The feminist translation theory emphasizes the subjectivity of the translator and does not pursue unreasonable fidelity to the original work. The strategies of feminist translation include prefacing, footnoting, supplementing and hijacking. Feminist consciousness can not only enrich translation theories but also provide ideas for cultural diplomacy. The purpose of this paper is to explore the relationship between cultural diplomacy and literary translation, and to describe the role of feminist translation theory in the relationship. Take "A Dream of Red Mansions" as an example to explain female translation and cultural diplomacy. Interacting with integrated factors, better translation should be used to consolidate cultural diplomacy.
\end{abstract}

\section{Keywords: Cultural diplomacy, Feminist Translation Theory, Translation.}

\section{INTRODUCTION}

\subsection{Cultural Diplomacy}

\subsubsection{Definition}

Scholars from all fields have different definitions for cultural diplomacy. Cultural diplomacy emerged after World War I, during which the United States government was under Thomas Woodrow Wilson. The world entered the twentieth century with a new characteristic: the world has begun to move towards pluralism which is full of diversification and complication. In such an era, the diplomatic strategy chosen by Wilson for the United States was based on its strong economy and advocated the collective security of peaceful settlement of disputes through communication and dialogue among countries. Therefore, people began to explore other diplomatic means besides politics and economy. The earliest "cultural diplomacy" appears in the Oxford English Dictionary in 1934. "The British Parliament has created a new means of cultural diplomacy, which is devoted to overseas English teaching". This view at present seems to be narrow. Until now, a definition of cultural diplomacy widely agreed by worldwide scholars can be basically summarized as: public diplomacy is normally defined in terms of those policies implemented by a state in order to create positive and beneficial impressions among the public of other states. There are three main ways of cultural diplomacy: government level (including international organizations and foreign art exhibitions), educational and cultural exchange activities (including students studying abroad and foreign cultural centers), and information exchange activities (books, films, and the Internet). In the process of cultural exchange, what is exported is not only cultural works but also the core values and country's traditions are transmitted. Nevertheless, the essential attribute of cultural diplomacy is still political, which is one of the diplomatic means of the government.

\subsubsection{Development}

The initial form of cultural diplomacy in the United States is educational exchange. In 1936, the government established the "The U.S. Information and Educational Exchange Act of 1948" initiative. The way to do this is through international exchanges of knowledge and skills. The success of the project turned culture communication into a major battleground. In 1950, the centerpiece of the Central Intelligence Agency (CIA) was the creation of the Congress for Cultural Freedom (CCF). The CCF bought thousands of copyrights to support the publication of many anti-communist classics of that 
period, such as Milovan Djilas's The New Class. And one of its most impressive achievements was a group of well-established literary and political magazines. CCF's flagship publication is Encounter, along with Preuves, Tempo Prelente, and so on.

A parallel with the United States is the development of cultural diplomacy in Europe. Europe is committed to exporting its culture through the building of institutions. In 1883, France was the first country to start the Alliance Française, a school of excellence dedicated to the spread of the French language. In 1934, the British Council was founded. His Majesty's Government provides $15 \%$ of the funding for this institution. The most noteworthy is the British cultural and creative industry, which has not only revived museums but also become a new cultural development prototype. Above all of these, various kinds of institutions present charming languages by introducing information about their own culture, society and political life.

China's case is somewhat unique. China seems difficult to trace the real origin because of that of thousand-year history. Zhang Qian, a messenger sent by Emperor Wu Di of the Han Dynasty to exchange spices and books with Western Regions, thus giving birth to the renowned Silk Road. The emperor of the Tang dynasty dispatched a monk "Xuan Zang"on a pilgrimage for Buddhist scriptures who brought back 657 Buddhist scriptures. Japan appointed a large number of diplomats and scholars to absorb Chinese architectural art, painting style and even music and dance. Many Chinese tomes have flowed into foreign countries such as The Four Books ("The Great learning", "The doctrine of the Mean", "The Analects of Confucius", "Mencius"), The Five Classics ("The Book of Songs", "The Book of History", "The Book of Changes", "The Book of Rites", "The Spring and Autumn Annals") and Four Great Classical Novels ("Water Margin", "Romance of the Three Kingdoms", "The Three Kingdoms Era", "The Journey to the West”, "A Dream of Red Mansions")

But since modern times, the form is also enriched because of the development of the network. In addition, it is worth noting that the American film industry has never been more successful as a means of cultural diplomacy. For example: In July 2020, the Forbes 2020 Top 100 Global Brands by Value was released, and The Walt Disney Company ranked 7th. Disney has reaped huge economic benefits by shaping the childhoods of a generation with its powerful cultural influence.

\subsubsection{Significance}

The role of cultural diplomacy is numerous. As the document of the State Department of the United States put it, through foreign translation, the cultural essence of the cultural product exporting country, namely its "national soul", can be revealed. Cultural diplomacy is an extension of traditional diplomacy. Traditional diplomacy usually refers to foreign communication activities such as visits, negotiations, representations, contract signing and meetings attended by state representatives. These contents mainly involve politics, economy and military. Willy Brandt, former foreign minister of West Germany, called cultural diplomacy "The third pillar of foreign policy" in 1966. In a nutshell, cultural diplomacy is conducive to expanding political and economic influence, promoting peaceful development and harmonious cultural exchanges.

To understand the role of cultural diplomacy, we need to distinguish some keywords. First of all, cultural diplomacy is also called public diplomacy, serving the overall national strategy. Cultural diplomacy is to influence other countries through a kind of " spiritual power" such as literature. This kind of spiritual power is "soft power" which was proposed by Joseph Nye in 1990. The ability to establish preferences tends to be associated with intangible power resources such as culture, ideology, and institutions. This dimension can be thought of as soft power, in contrast to the hard command power usually associated with tangible resources like military and economic strength. Secondly, the American politician K.E. Boulding believes that the country's image as one of the integral components of the "soft power" could reflect the comprehensive strength and influence of the country from one aspect. Therefore, the shaping and dissemination of national image is highly valued by governments of various countries. To sum up, cultural diplomacy can retrench cultural divide, update the image of the country leading to soft power.

\section{FEMINIST TRANSLATION THEORY}

\subsection{Definition}

Feminist theory originated from the second wave of the American feminist movement in the 1960s. It is committed to changing the gender bias of traditional society and subverting the patriarchal thought of binary opposition in the western hierarchy. In the field of literary criticism, feminists used to believe that traditional criticism solidified male identity and exacerbated social prejudice, while Kate Millett published "Sexual Politics" to counter derogatory images of women. Feminist Criticism-a mode of literary and cultural discussion and reassessment inspired by modern feminist thought-has been included in the Oxford Dictionary of Literary Terms.

The term "gender" was first put forward by American anthropologist Gail Lubin to distinguish it from biological sex. Previous feminists tended to improve the social status and plight of women. Later translators paid attention to "female" as a way of expression and discourse type. The theory of female translation is no longer based on the limited "nature" of gender, but extends to social experience. 


\subsection{Applications and Problems}

Luise Von Floto, a Canadian female translator, summed the strategies of feminist translation up prefacing, footnoting, supplementing and hijacking. The prefacing and footnoting strategy is to add explanations to the original text making the meaning clearer where is the place to explain the background, intent, translation strategy and translation process. It allows the reader to fully understand the translator's thinking, especially their feminist identity. This is the most common approach in female translation theory. Chinese scholar Qian Qing gives a guide to Deborah L. Madsen's book "Feminist Theory and Literary Practice", detailing the author's life, the history of the feminist movement and the work's merits. In her writing, women's rights are a complex philosophical issue, while expressing agreement with the author's views.

Hijacking is one of the most controversial aspects of female translation theory. Feminist translators are apt to rewrite the words which they considered were not suitable for their theory. To emphasize women's statues and gender distinguish, the hijacking method has weakened the male in the original text. There are two main situations of hijacking. One is to create new words, such as Lotbiniere Harwood's own creation: "anther shelove". Another is appropriate rewriting. For example: In the "Bible": Jesus said to them, I am the bread of life; he who comes to me shall not hunger, and he who comes to me I will not cast out. And Joann Haugerud translated that: Jesus said to them I am the bread of life; anyone who comes to me shall not hunger, and anyone who come to me I shall not throw out.

Joann Haugerud replaced "he" with "anyone". At that time, the patriarchal civilization was highly developed. God was biased towards fatherhood, not asexuality. It is well known that a woman is a rib on a man's body, and the subsidiary status of women is obvious. The Bible is the world's most widely distributed book, and it is clear that unequal gender concepts have also spread.

Supplement refers to the addition of details or explanations by the translator during the translation process. One particular salient example is the English translation of <The injustice of Dou'E>. Stephen translated as: I've brought my daughter straightaway to you today, Madam. Dare I say she'll become your daughter-in-law? Simply use her as you will. The application like 'today' 'dare' 'use' is to highlight the oppression of women at the time.

Adding is actually a more common approach. From a cultural perspective, we must add a sense of locality based on foreign culture. Feminist translation theory adds words, phrases, and even punctuation to highlight the status of the female character itself. It is an intervention that compensates for the differences between the two languages.

In 1654, the renowned French translator Gilles
Menage made up the famous pun 'les belles infidelles' standing for "a disloyal beauty" or "a beautiful but faithless translation". In the thoughts of men, women are either faithful or beautiful. Both sides always seem to be extremely irreconcilable. Such a thinking pattern that sets "beauty" and "faithfulness" in opposition makes people also set the gendered translation standard "faithfulness" and "elegance" in opposition. Making good use of female translation theory can not only enrich articles, but also help to spread correct culture. Excessive use can only damage literature itself.

\subsection{The Relationship between Cultural Diplomacy and Female Translation Theory}

It is true that there are not many articles on cultural diplomacy and translation, and even fewer have been written about it in relation to women. Why do we choose translation as the entry point of cultural diplomacy? Luise Lov Floto believes that in cultural or public diplomacy, the government often pays attention to the cultural elite of a country. These elites include politicians, media workers, professors and students, publishers, and the culture-minded elite. They also tend to focus on high literature -- and the same is true for translators. As a special spiritual product, literature records the unique ideology and culture of human beings. The overseas dissemination of excellent works helps to build a good national image. Shakespeare's works promote the development of the English language, and also propel the prosperity of drama on a global scale; Charlotte Bronte's "Jane Eyre" reflects the reality of paying attention to the female group, which has improved the image of women to a certain extent.

As mentioned above, the essential attribute of cultural diplomacy is sociality. The attribute of female translation theory is also social. The common purpose of both of them is to achieve their own demands through their works. Cultural diplomacy emerged precisely to avoid the collision between economy and military. Female translation theory is also a moderate but effective force in the feminist movement. In the translation of works, the theory of female translation is helpful to correct the problems involving gender discrimination, racial discrimination and even improper translation in the works. This provides a solid foundation for other countries to have a correct understanding of their own culture.

\section{FEMINIST TRANSLATION THEORY AND CULTURAL DIPLOMATIC WORKS IN CHINA}

\subsection{Historical Development}

Actually, China has not had a thorough feminist movement for sake of its cultural continuity and turbulent situation of modern times. The continuous inheritance of Confucian culture solidified people's 
thoughts and weakened the awareness of women. Years of war made women have no time to pay attention to their own thoughts. All of these have made gender studies accessible to the public only in contemporary times. In China, it was not until the year 2000 that Chinese scholars paid attention to feminist translation studies. This is precisely because Chinese female translation studies are relatively moderate with no serious conflicts.

In 1999, a Professor Mu Lei from Guangdong University interviewed Jin Shenghua, a female translator, which attracted people's attention. The content of the interview was gender as a translation factor. And in 2000, "A research into contemporary Western Translation Theory" introduced the influence of western feminism on translation.

\subsection{Work analysis}

In this part, "A Dream of Red Mansions" will be present when studying feminist translation and cultural diplomacy. As a representative of traditional Chinese culture, it was first translated by British missionaries in 1816. Its rich description of female characters describes a scroll of social customs. Arthur Waley, a famous British Sinologist, said that "The Dream of the Red Chamber" (another translation of the name of "A Dream of Red Mansions") may be the first full-length realistic novel in China, which is different from ordinary historical novels, but an epitome of the whole feudal society. The Dream of the Red Chamber" is the wealth of world literature. Its appearance adds glory and honor to world literature, and it benefits the creators of world literature greatly."

\subsection{1 “A Dream of Red Mansions" Translation}

Two English translations of " $A$ Dream of Red Mansions" appeared in the 1970s. The British David Hawkes made great efforts to translate into "The Story of the Stone" which reported Chinese customs and social culture. This version is more suitable for the West to understand Chinese tradition but still adequate enough. In 1978, famous couple Yang Hsien-yi and Glad-ysYang jointly translated "A Dream of Red Mansions". Dai's identity as a woman makes the translation more relevant to the source language. Dai's identity as a woman makes the translation more relevant to the source meaning. However, political nature circled the bounding area.

In production, the author reveals the low-status and inequality of women in feudal society from the treatment of women's names and addresses which were the privilege of men. For example, a man could marry several women. In order to distinguish the different position and identity of those which obliterates the subjectivity of female existence, people often use special appellation. Glad-ysYang translated one of the women of the lord into Concubine Zhao while David
Hawkes interpreted Aunt Zhao. Concubine, a woman who lives and has sex with a man she is not married to, and has a more social rank than his wife or wives. Indeed, David Hawkes was completely faithful to the source word. In comparison, Glad-ysYang uses a more appropriate description because she understands the female identity and conveys it.

Besides, the titles of the two versions are quite different. The renowned Chinese litterateur Qian Zhongshu once praised Hawkes's chock. Hawkes's translation abandoned "A Dream of Red Mansions" and titled it "The Story of the Stone". The reason for this choice is that the symbolic meanings of "red" in Chinese and English cultural contexts are widely divergent. If the word "red" was used, British readers would inevitably misunderstand the title of the book. The agreement is red symbolizes cruelty and bloodshed and on behalf of radical and violent revolutions such as red activities; It also denotes debauchery and obscenity, such as the red light area. Conversely, Yang translated "A Dream of Red Mansions" literally, and retained two important images: "Dream" and "Red". "Dream" is the social metaphor of the elapsed prosperity and the concept of empty and nihilistic life. In Chinese culture, "red" is closely associated with enthusiasm, happiness and women, etc. In modern times, it has more revolutionary significance.

As mentioned above, Yang's translation has a strong political character. Glad-ys Yang experienced the impact of the "Cultural Revolution" and even the disaster of imprisonment. Publishers' requirements for work were to spread ideology. It is an indictment of one's own experience and the demands of the age that made the article very political. It happens that $<A$ Dream of Red Mansions $>$ is a satire on the historical background and the status of women. For westerners, the first thing to do for cross-cultural works is to comprehend, which dilutes the original expression of female consciousness.

The overseas spread of "A Dream of Red Mansions" is of positive significance. First of all, it contains the idea of social progress. The West has been stressing freedom and democracy since Athenian and Roman times. Both teemed with coincidence spiritually. Secondly, this article has reached the stage of popular novels from elite culture: it has research value and universal appreciation value that allows for a wider target market. Finally, it can show the excellent cultural image of China. The world depicted in the work reflects the Chinese people's pursuit of a better life and the historical heritage they have.

\subsection{2 "A Dream of Red Mansions" Application}

The president of the People's Republic of China Xi Jinping has proposed that "cultivating and carrying forward core socialist values must be based on fine traditional Chinese culture" and that "building a strong cultural country must be based on the foundation of fine traditional Chinese culture, absorb nutrients, gain 
strength, and endue the spirit of The Times". "A Dream of Red Mansions" and its accompanying culture have become a widely discussed and used cultural element. From the works, people can not only feel its unrivaled artistic achievements, but also feel that it contains the strong and profound feelings of traditional Chinese culture. Therefore, President Xi Jinping mentioned that to show the soft power of the motherland's culture on his several overseas visits. As the source of cultural creativity, "A Dream of Red Mansions" has been deeply integrated into all aspects of people's lives. Successful examples of cultural creative industries based on it include Rongguo Mansion and Ningrong Street in Zhengding County, Hebei Province, Prince Kung's Mansion and Grand View Garden in Beijing. Now it has become a famous cultural tourist resort at home and abroad, as well as a cultural base promoting the contemporary dissemination of A Dream of Red Mansions. As an interdisciplinary discipline, now there are also overseas associations dedicated to the study of the composition, which has become an opportunity for people from all over the world to communicate.

\subsection{Existing Problems}

Feminist translation theory has a huge impact on cultural diplomacy, but it also has some problems. The most basic thing is that the number of people who study is scarce. According to statistics, between 2002 and 2016 , the total number of papers on feminist translation studies in China has reached 559, with an average annual publication of 37.27 . In the West, as translation is not the mainstream and some translators are too radical, there is not much relevant research.

On the whole, translation can be described as confusion, mainly reflected in the name above. The confusion of people's names is most common, with names like Fitzgerald translated as: 斐兹杰惹, 菲茨杰 拉德, 菲兹杰拉德, 费兹杰拉德, 菲茨杰拉尔德. Without a uniform standard, the difficulty of dissemination will rise. The dispersion of search terms adds resistance to cultural communication.

Then, under the influence of conservative ideas and radical feminism, the anti-feminist movement began with vitality. The first important event in the movement against women's suffrage is generally considered to have been the publication of "An Appeal Against Woman Suffrage" in the 19th Century in June 1889. External pressure and the division of their own factions have seriously damaged the development of literary theory and social stability.

\section{STRATEGY ANALYSIS}

\subsection{Strengthen Cultural Diplomacy}

Here's a report on China. According to the "China in the Eyes of Americans" survey conducted by Shanghai Jiao Tong University, $64 \%$ and $61 \%$ of Americans, respectively, believe that China has international economic competitiveness and political influence. But 72.5 percent do not consider China has popular a culture. The result of this survey shows that China's government has adopted a series of measures to strengthen cultural output, but the intensity is lacking in effect. Bias still exists because of cultural clashes and stance issues. To get out of this predicament, the first step is to reverse cultural prejudice.

The United States has always attached great importance to cultural promotion and strengthened its global cultural influence, which is a necessary strategy for the United States. The United States has always regarded its values of "democracy and freedom" as its primary point. Since the 18 th century, the successful shaping of the "American Dream" has firmly held the strong position of the American Center. After World War II, American international cultural institutions developed rapidly. Secondly, the United States has passed some laws to guide foreign cultural exchanges. For example, in 1946, the United States passed the Fulbright act, which provides financial support for American scholars and students who go abroad as well as people who visit and study in the United States from other countries. Third, the U.S. government emphasizes the diversity and extension of cultural diplomacy. International students in the United States are required to learn politics and cultures. Since then, the U.S. government has also carried out foreign cultural assistance, and a large number of doctors, teachers and missionaries have been sent overseas.

As far as the domestic cultural market of the United States is concerned, trade protectionism makes less than $1 \%$ of the cultural products from overseas. In 1958, the United States signed an agreement with Poland-The United States exported cotton and other agricultural products to Poland and provided tens of millions of US dollars in loan agreement, with the additional condition that Poland must purchase millions of US dollars in films, books and copyrights from the United States. There is no doubt that American films occupy the world film market. The annual income of the Hollywood film and television industry in the overseas market is more than 3 billion US dollars, which has also affected generations of people. The American government attaches great importance to the role of mass communication tools. English is the universal language in the world. The United States spared no effort to make use of the advantages of English, mainly through film and television, news, computers, software and so on to dominate international culture. The successful experience of the United States can be used for reference.

In China, "The Belt and Road" initiative has also opened up a channel for cultural exchange. Confucius Institute has been established to promote Chinese all over the world. The form of cultural diplomacy cannot be single. In the past, there were excellent successful diplomatic experiences like "Ping Pong Diplomacy" and 
"Panda Diplomacy". In addition, the following methods can be used:

-Increase opportunities for educational exchange, especially among young people

-Increase the exchange of cultural works, such as book exchanges

Encourage the translation of multiple works

Pay close attention to personnel training

Set up international exchange foundation and cultural exchange awards to improve the quality of cultural exchanges

- Build cultural brands and expand brand influence

-Establish an integrated cultural industry

- Make use of existing successful diplomatic examples and innovate for development

-Ensure funding to smooth exchanges

-Utilize effectively existing technology to propagate culture through various channels

Combine official dissemination and non-governmental self-communication rumors

Regulate public opinion and avoid malicious

Cultural diplomacy could overcome language barriers, cultural prejudices and ideological differences through these actions.

\subsection{Strengthen the Application of Female Translation Theory in Works}

The central theory of female translation is the so-called creative treason--breaking the grammatical structure of the original text and rewriting it. It is important not to be too "rebellious" if you want to strengthen the application of theory. The replay strategy is a very good way to neutralize. The reproduction strategy is to retain the main line of the original text and so on. The female translation theory puts the subject, object and exposition of language above the female perspective, and breaks down the traditional gender discrimination with the difference and equality. The core is still gender equality, so adding too much political economy would spoil the essence. In the future, female translation should move towards a peaceful process, with symbiosis as the leading role and gender harmonious symbiosis as the emphasis. The construction of gender equality can also be diversified. Today, as the status of women has been greatly improved, female translators can put more energy into the protection of women's rights and the diversification of gender equality.

\section{CONCLUSION}

In 2013, Luise Von Flotow was invited to attend the lecture by Beijing Foreign Studies University. She pointed out that since the 1990s, the field of feminist translation has entered a period of dreariness due to the expansion of the "gender" theory and the emergence of "queer theory". As a well-known female translation theorist, she argued that most of the translation she was engaged in is not complete feminist translation, occasionally at the appropriate time under the right circumstances. Female translation theory appears in the time and place as a way of expression. Whether the translator thinks it is appropriate or not is the main issue. Too radical and unfaithful translation has gone beyond the basic scope of translation. In feminist translation theory, many things are well-worth learning, especially in cultural diplomacy. At present, there is a big gap in gender balance in some regions. Religion and convention not only affect their own thoughts, but also imprison the opportunities for development. In a sense, women's status largely determines the future of the country. Because there are only two kinds of people in the world: men and women. When women's status rises, the power of the country will achieve the effect of $1+$ $1>2$, on the contrary, it will be less than two. Literary translation provides a great treasure house for cultural exchange. Countries should actively carry out cultural diplomacy, strengthen cultural exchanges and deepen mutual understanding so as to overcome cultural prejudices, so as to realize a real cultural power.

\section{REFERENCES}

[1] Bennett O. (2016) Cultural Diplomacy and International Cultural Relations in Twentieth-Century Europe. Contemporary European History, 25(02):373-385

[2] Miu KJ. (2006) A Study of Chinese Cultural Diplomacy. D.Party School of the CPC Central Committee, 12:109-125

[3] US Depamnent of State. (2005) Cultural Diplomacy-The Linchpin of Public Diplomacy Report. http://www.state.gov/doolments/organizafion/5437 4.pdf (accessed February, 12th, 2014).

[4] Nye Jr, JS. (1990) Bound to Lead: The Changing Nature of American Power. American Political Science Review, New York.

[5] Chris, B. (2008) The Oxford dictionary of literary terms. Oxford University Press, Cambridge.

[6] Moody D. (1959) God's Only Son: The Translation of John 3:16 in the Revised Standard Version. The Bible Translator. 10(4):145-147.

[7] Flotow, LV. (2007) Translating "High" Literature for Public Diplomacy. In Miguel Angel Montezanti(eds.). Viajes, Identidades, Imperios. 
Imaginarios ingleses, en Cultura, Literatura y Tradducion .Tomo I. La Plata: Universidad Nacional de La Plata. pp.77-79.

[8] Tsao, HC., Kao, O., Wang, CC., Doren, MV. (1959) Dream of the Red Chamber. Vision Press Limited, Hongkong.

[9] Yang, XY., Dai, ND. (1994) A Dream of Red Mansion. Foreign Language Press, Beijing.

[10] David, H. (1974) The Story of the Stone. Penguin Group, London.

[11] Xi, JP. (2014) Young people should consciously practice core socialist values. People's Daily, 66:002.

[12] Liu, MY. (2018) Feminist Translation Studies in China in the Past 15 Years (2002-2016) : A Statistical Analysis of 559 CNKI Journals. Journal of University of Shanghai for Science and Technology (Social Science Edition), 40(04):320-327.

[13] People's Daily. (2011) Americans are more favorable to China and their cultural awareness of China is still weak.http://www.gov.cn/jrzg/2011-01/31/content_1 796299.htm

[14] Chen, XR. (2010) Exploring Canadian Feminist Translation theory. Foreign Language Teaching and Research Press, Beijing. 